\title{
Structured Content Reading Instruction vs. Direct Instruction: Their Implication on Students' Achievement, Reading Comprehension and Critical Thinking in Mathematics
}

\author{
Rizhaly B. Maandig ${ }^{1, *}$, Laila S. Lomibao ${ }^{2}$, Charita A. Luna ${ }^{3}$ \\ University of Science and Technology of Southern Philippines, Lapasan Cagayan de Oro City \\ *Corresponding author: rbmaandig@gmail.com
}

\begin{abstract}
Teaching students to read mathematically through the use of reading strategies train them to think critically and comprehend mathematics text. Reading strategies were so popular and proven effective in teaching language, but their effectiveness in mathematics classroom remains controversial among mathematics teacher. Hence, this study was undertaken to determine the significant impact of two approaches of teaching: structured content reading instruction and direct instruction on students' mathematics achievement, reading comprehension and critical thinking skills. Structured content reading instruction was well designed reading instruction that exposed students to reading strategies during pre -reading, during and post reading activities. Direct instruction was highly organized teacher led instruction that engaged students to daily review, corrective assessment and independent practice. The participants of the study were four intact classes at PHINMA Cagayan de Oro College. Pretest posttest quasi-experimental control group designed were used as research design. Analysis of covariance revealed that there is evidence that structured content reading teaching approach has improved the scores of the students in reading comprehension test. However for achievement and critical thinking, the effects of structured and direct instruction are comparable. The result implied that structured content reading instruction is effective in improving students' reading comprehension. Hence, the researcher recommends that teacher may use both methods in teaching mathematics to enhance students' reading of mathematical terms, achievement and critical thinking.
\end{abstract}

Keywords: mathematics reading comprehension, mathematics achievement

Cite This Article: Rizhaly B. Maandig, Laila S. Lomibao, and Charita A. Luna, "Structured Content Reading Instruction vs. Direct Instruction: Their Implication on Students' Achievement, Reading Comprehension and Critical Thinking in Mathematics.” American Journal of Educational Research, vol. 5, no. 5 (2017): 574-578. doi: 10.12691/education-5-5-16.

\section{Introduction}

The deteriorating performance of Filipino students in the national and international mathematics tests for the last decade has become a major challenge to Philippine education [16]. Balbalosa [6] said that mathematics performance of Filipino students in national achievement as well as the international achievement has been consistently low, and the situation in local levels is similar. Even the selected students from the Science High School of the Philippines rank tenth among the ten countries piloted for study [23]. Performance of elementary and high school in National Assessment Test (NAT) is below 75\% [20]. Generally Filipino students did not perform well in their mathematics classes.

There are identified factors why our performance in mathematics is deteriorating. Adava's [5] findings revealed that one of the factors that affect achievement in mathematics is instructional factors. Also, the Department of Education credited poor achievement in mathematics to students' poor reading comprehension.

Several programs were created just to raise the performance of Filipinos in mathematics. The Department of Education in partnership of World Bank implemented the Learning, Equity, and Accountability Program Support Project (LEAPS). According to Education Secretary Bro. Armin Luistro, "LEAPS will strengthen accountability and incentives for teachers; improve teaching and learning in early grades, especially in reading and math; and address the needs of our disadvantaged learners" [30]. Hence, the enhanced basic Education Curriculum, k -12 (DepEd Order No. 73, series 2012) [9] and the enhance Commission on Higher Education faculty development, and research on education programs [12] were implemented. These are projects and movements towards improving quality instruction including not only for mathematics performance but reading comprehension and critical thinking as well. The focus of these programs highlighted training in teaching strategies, identifying effective teaching strategies, and designing functional 
curriculum. In line to the global effort of improving student's achievement in mathematics, reading comprehension and critical thinking, the researchers would like to test the implication of two teaching strategies: structured content reading instruction and direct teaching instruction towards the above domain.

\subsection{Content Reading Strategies}

Reading is the initial skill necessary for students to learn in content areas from early childhood education to higher education [7]. Understanding all subjects including mathematics requires basic skills in reading (Adams, et al, 2015) [2]. This skill must progress as students promoted to higher academic level. As students enrolled to the next level text to read becomes more and more complicated. That is why classroom instruction must provide opportunities for students to develop their reading skills.

Reading mathematics text deemed more complex and extremely difficult. Unlike other content areas, mathematics text includes conceptual definitions, mathematical expressions, procedures, and processes. Students need to focus and engage in the text while reading. According to Shanahan and Shanahan [27] readers need to analyze and expand meaning rather than condense ideas. She added to comprehend mathematics text most students require explicit instruction in the specialized structure, language conventions, and interpretive processes used in these texts. Mathematics instruction that include reading instruction, particularly reading strategies provides a scaffold for students to build comprehension of the mathematics content materials being read.

Content reading strategies are methods that used reading tools to facilitate comprehension of text. These are tools for learning [29]. Content reading strategies can help students increase and deepen their comprehension for content area information, especially if these strategies are taught explicitly by their content area teachers [26]. She added that students need to use reading strategies to help them understand what they read [18].

Mathematics instruction that incorporates reading and use reading strategies motivates students to decipher every line in mathematics text. It activates students' background knowledge and uses it to understand the present lesson. Reading tools help facilitate students' engagement in the text. Activation of prior knowledge, motivation to read engagement in the text and critically understand mathematics concepts are some important factors brought by implementation of reading strategies that leads to high performance in mathematics.

There were studies that associate reading to mathematics performance and choice of course. Jiban [17] reported that reading uniquely and significantly contributes to the prediction of both mathematics achievement and mathematics course level placement. Rust [25] also found out that weaker implementation of the reading strategies was associated with lower student performance in developmental mathematics. Near [21] in her study Literacy Instruction in Math Classes reported that use of read strategies is positively correlated to mathematics achievement.

Some studies include implementation of reading strategies. Hite [15] in her study "Improving Problem Solving by Improving Reading Skills” revealed that some individuals improve on their abilities to focus on and solve word problems by implementing reading strategies. Fantilaga [13] found out that content literacy strategies (using reading strategies) had improve students' performance in chemistry. Although there were few studies regarding the effectiveness of content reading strategies, the researcher would like to back up this method through verifying its usefulness in mathematics classroom.

\subsection{Direct Teaching Approach}

Researchers defined direct instruction as interaction between students and teachers where the teacher conducts a well planned, organized, and highly sequenced lecture and give guided practice or drills to students. It is popularized by Engelmann, \& Carnine [11] that said "teachers teach when students learn". It is synonymous with phrases like teacher-directed instruction and explicit instruction. Holloway [14] agreed that it refers to a rigorously developed, highly scripted method for teaching that is fast - paced and provides constant interaction between students and the teacher.

The method adjudged as traditional math instruction where the teacher conducts only lecture minus students practice until mastery of mathematics concepts and processes are evident. Direct teaching approach is much more than a lecture. Lecture is just part of it. It is teacher directed instruction where materials are so organized from simple to complex mathematics concept, through which students were provide with comprehensive practice and corrective feedback until mastery is attained.

Some researchers described direct teaching as the most powerful method. Lindsay [19] asserted that direct instruction provides powerful evidence of success in learning mathematics and other field of studies. Ewing [10] in his review of recent studies said these studies revealed student progress in mathematics as benefit of direct instruction. Alfieri et al. [3], Hatie and Yates (2013) as cited by Stokke [27] said that examples, scaffolding, clear explanations and consistent feedback are exceptionally beneficial for learning concepts and processes.

Studies also support that direct instruction really an effective methods especially in teaching mathematics. Oladayo [22] in his quasi experimental research designed concluded that direct instruction had better effect on students' mathematics achievement than indirect instruction when teaching mathematics lessons among junior secondary school students. Al-Makahleh [4] confirmed through his study that direct instruction strategy effectively improved mathematics achievements of students with learning difficulties. Conley [8] suggested that direct instruction principles are effective in supporting students with varied achievement levels and that these principles can be used to enhance comprehension among students at very different points in reading development. She added that direct instruction can be designed to support complex learning and the development of higher order cognitive strategies. With the sprout of research in teaching methods direct teaching usually compared to more interactive teaching methods and often judged as traditional and not effective. This study implements true direct teaching approach and want to verify its effectiveness in teaching college algebra. 


\section{The Method}

The research employed a quasi - experimental nonequivalent control group pretest - post-test design and four sections out of 28 sections first year college students of PHINMA Cagayan de Oro College were participants of this study. Two intact sections were assigned randomly as experimental group and the other two sections as control group. The experimental groups were exposed to structured content reading instruction while the control groups to direct instruction. Pre test and posttest of mathematics achievement test, reading comprehension and critical thinking test were administered before and after the experiment. All instruments used were validated and have a reliability index greater than 0.50 . Data gathered were analysed using analysis of covariance (ANCOVA), mean and standard deviation.

In the experimental groups, the teacher implements reading as strategy. This strategy was implemented through the use of reading tools and mathematics content material. Some of these reading tools used were anticipation guide [1], front load a word, student generated questions, bubble chart, rectangular form, comparison matrix, another kind of outline, pause and reflect, question frame, journal entry, cloze paragraph and KWL. These reading tools were used by students during pre reading, during reading and post reading activities. During post reading, students (one or two groups) present, explain their output and solve exercises.

In the control groups students were exposed to direct instruction. The teacher used the model of Rosenshine [24] where the teacher followed the sequence: 1 . offer daily review, 2. present new content, 3 . give initial student practice, 4 . provide feedback and corrective assessment, 5. provide independent practice, and 6 . offer weekly review. In this group the teacher led the discussion followed by group and independent practice. The teacher grouped students during initial students' practice.

Both groups had copy of mathematics content material and exposed to grouping while doing the activity. The same assignment and quizzes were given.

\section{Results and Discussion}

Results of data analysis are presented in the following tables.

Table 1. Means And Standard Deviation of Pretest and Posttest Scores in College Algebra Achievement Test

\begin{tabular}{ccccc}
\hline & \multicolumn{2}{c}{ Control Group } & \multicolumn{2}{c}{ Experimental Group } \\
\hline Groups & Pretest & Posttest & Pretest & Posttest \\
Mean & 11.69 & 18.55 & 11.72 & 18.57 \\
SD & 2.99 & 6.5 & 3.4 & 6.9 \\
\hline
\end{tabular}

Table 1 shows the means and standard deviation of pretest and posttest score in College Algebra achievement test. The control group obtained a mean score of 11.69 $(\mathrm{SD}=2.99)$ in the pretest while the experimental group had a mean of 11.72 (3.4). This result revealed that in both groups, students' background about college Algebra was below $50 \%$ of the total items considering that the total number of items is 36 . With a difference of 0.03 , it can be inferred that initial performance of students in both groups are comparable and below the minimum passing score. Students' abilities in both groups are similar as evident in the standard deviations of their scores in the pretest.

However, their scores increased after the administration of the treatment. This was evident in their post-test mean score of 18.55 and 18.57 for the control and experimental group respectively. The performances of both groups in the posttest were above 50\%, the minimum passing mark for the subject. An increase of 6.86 and 6.85 points of the scores of control group and experimental respectively was noticeable. To determine the effect of the treatment, further analysis was done.

Table 2. Summary Of One - way ANCOVA of Pretest and Posttest Score of Math Achievement Test

\begin{tabular}{cccccc}
\hline Source & SS' & DF & MS' & F & P \\
\hline Treatment & 179.53 & 1 & 179.53 & 4.11 & $0.05^{*}$ \\
Error within & 4319.62 & 99 & 43.53 & & \\
Total & 4499.15 & 100 & & & \\
\hline
\end{tabular}

*not significant at 0.05 .

Table 2 shows the result of the analysis of covariance of pretest and posttest scores of in mathematics achievement test. The ANCOVA yielded a probability value equal to 0.05, the significance level. This result led to the acceptance of the null hypothesis. This implies that there is no significant difference between the scores of the two groups, which means that structured content reading instruction is as good as direct instruction. Since average performance of both groups was above the minimum passing score (50\%),therefore, both structured reading instruction and direct instruction are effective in raising academic gains of students in college algebra.

Table 3. Means and Standard Deviation of Pretest and Post test Scores in Reading Comprehension

\begin{tabular}{ccccc}
\hline & \multicolumn{2}{c}{ Control Group } & \multicolumn{2}{c}{ Experimental Group } \\
\hline Groups & Pretest & Posttest & Pretest & Posttest \\
Mean & 5.24 & 5.61 & 5.02 & 6.28 \\
SD & 1.76 & 1.60 & 1.73 & 1.64 \\
\hline
\end{tabular}

Table 3 shows the means and standard deviation of the pretest and post test scores in Reading Comprehension test. The pretest scores of both control groups and experimental groups in reading comprehension test were below 50\%. Initially, the control group can comprehend mathematics text better than the experimental group. But after the treatment, result of posttest indicated that the experimental group can comprehend mathematics text better than the control group. A difference of 1.26 was noted.

Table 4. Summary of one - way ANCOVA of Pre-test and Post-test Score in Reading Comprehension

\begin{tabular}{cccccc}
\hline Source & SS & DF & MS & F & P \\
\hline Treatment & 21.27 & 1 & 21.27 & 8.74 & $0.04^{*}$ \\
Error within & 241.04 & 99 & 2.43 & & \\
Total & 262.21 & 100 & & & \\
\hline
\end{tabular}

* significant at 0.05 . 
As shown in Table 4, the analysis of covariance yielded a probability value of 0.004 which is lesser than 0.05 , the significance level. The result led to non acceptance of the null hypothesis. This means that there is significant difference between the mean scores of the two groups in reading comprehension. Since the experimental group obtained higher mean, therefore structured contentment reading instruction is better than direct instruction in improving reading comprehension of college algebra students. This further implies that students who are exposed to reading with the use of reading strategies had improved more in their reading comprehension skills.

Table 5 shows the mean and standard deviation of pretest and post-test in critical thinking test. The control group obtained higher score in critical thinking test than the experimental group. A slight difference, 0.09 made the control group better than the experimental group in terms of critical thinking. However, after the treatment was implemented the experimental group scored higher than the control group in critical thinking test. A difference of 0.19 placed experiment groups’ performance on top of the control group.

Table 5. Means And Standard Deviation of Pretest and Post test Scores In Critical Thinking

\begin{tabular}{ccccc}
\hline & \multicolumn{2}{c}{ Control Groupd } & \multicolumn{2}{c}{ Experimental Group } \\
\hline Groups & Pretest & Posttest & Pretest & Posttest \\
Mean & 2.21 & 2.35 & 2.12 & 2.52 \\
SD & 1.12 & 1.25 & 0.91 & 1.38 \\
\hline
\end{tabular}

Table 6. Summary of one - way ANCOVA of Pre-test and Posttest ScoreIn Critical Thinking

\begin{tabular}{cccccc}
\hline Source & SS' & DF & MS' & F & P \\
\hline Treatment & 5.52 & 1 & 5.52 & 3.27 & $0.073^{*}$ \\
Error within & 166.84 & 99 & 1.69 & & \\
Total & 172.36 & 100 & & & \\
\hline
\end{tabular}

$*$ not significant at 0.05 .

Table 6 shows the result of one - way analysis of variance (ANCOVA) of the pre-test and post-test scores in critical thinking skills. The analysis yielded a probability value of 0.07 which is greater than 0.05 , the significance level. This led to the none rejection of null hypothesis that there is no significant difference of the participants' critical thinking skills as influence of the type of instruction. This implies that students in both groups have comparable critical thinking skills. When students are exposed reading mathematics text they will analyze the text while reading. Reading tools engage students while reading and thus helping students facilitate understanding of concepts and processes. Performing activities in the classroom like in drills and completing reading tools while reading are worthwhile experience that stimulates the brain to think and therefore enhance critical thinking. The research done in a short period of time has enhanced the students' critical thinking skills.

\section{Conclusions and Recommendation}

Based on the analysis, the researcher concluded that structured content reading instruction is better than direct instruction in improving reading comprehension in mathematics. Both mathematics instructions are equally effective in teaching college algebra and developing students' critical thinking skills. Hence, the researcher recommends that teacher may use both methods in teaching mathematics to enhance students' reading of mathematical terms, achievement and critical thinking.

\section{References}

[1] Adams, A.E., Pegg,J., \& Case, M. (2015). Anticipation guides: reading for mathematics understanding," National Council of Teachers of Mathematics (NCTM), 108 (7), Retrieved from http://www.nctm.org.

[2] Adams, A. E. (2009). Teacher's use of literacy in Secondary math classes (Doctoral Dissertation). Available From ProQuest Dissertations \& Theses Global database. (UMI 3360841).

[3] Alfieri, L., Brooks, P. J., \& Aldrich, N.J. (2011). Does Discovery based instruction enhance learning? Journal of Educational Psychology, 103(1), 1-18.

[4] Al-Makahleh, A. A. A. (2011). The effect of direct instruction strategy on math achievement of primary 4th and 5th grade students with learning difficulties. International Education Studies, 4(4), 199-205

[5] Andava, O. (2016). Factors that affect mathematics achievement of students of Philippine normal university - Isabela campus. Asia Pacific Journal of Research, 2(37), 108.

[6] Balbalosa, J. F. (2010). Factors affecting the mathematics performance of laboratory high school of Laguna State Polytechnic University academic year 2009 - 2010. (Unpublished master's thesis). Laguna State Polytechnic University, Siniloan, Laguna.

[7] Cahoon, B. L. (2007). Literacy across the curriculum: Teachers' teaching teachers about content area reading strategies and their perceptions of the effectiveness of these strategies (Master's thesis). Available from ProQuest Dissertations \& Theses database. (MR 36303).

[8] Conley, T.M., \& Gil, E. L. (2011). Information literacy for undergraduate business students: examining value, relevancy, and implications for the new century. Journal of Business and Finance Librarianship, 16(3), 213-228.

[9] DepEd Order No. 73. (2012). Department of Education Philippines. Retrieved from http://www.gov.ph/downloads /2012/09sep/20120905-DepEd-DO0073-BSA.pdf.

[10] Ewing, B. (2011). Direct instruction in mathematics: issues for schools with high indigenous enrollments: a review. Australian Journal of Teacher Education, 36(5), 65-92.

[11] Engelmann, S. \&Carnine, D. (1991). Theory of instruction: Principles and applications(Rev. ed.). Eugene, OR: ADI Press.

[12] Faculty Development Program (FacDev). (2017). Commission on Higher Education. Retrieved from http://ched.gov.ph/central/page/faculty-developmentprogramfacdev.

[13] Fantilaga, R. (2009). Effects of chemistry lessons using Content reading literacy strategy activities. (Unpublished master's thesis). Bukidnon State University, Malaybalay City.

[14] Holloway, J. K. (2012). Teachers' concerns, attitudes, Beliefs, and pedagogical practices as it relates to Technology integration (Doctoral Dissertation). Retrieved from

https://etd.auburn.edu/bitstream/handle/10415/3195/Holloway_dis sertation_final.pdf?sequence $=2$.

[15] Hite, S. (2009). Improving problem solving by improving reading skills. (Master's thesis). Retrieved from http://digitalcommons.unl.edu/cgi/viewcontent.cgi?article=1016\& context=mathmidsummative.

[16] Imam, O. A., Mastura, M. A. \& Jamil, H. (2013). Correlation between reading skills and student's performance. International Journal of Evaluation and Research in Education (IJERE), 2(1), 1-8.

[17] Jiban, C.L. (2006). The role of reading proficiency in mathematics achievement score and course taking Disparities (Doctoral Dissertation). Available from ProQuest Dissertations \& Theses Global database. (UMI 3243347). 
[18] Klingner, J. K., Urbach, J., Golos, D., Brownell, M., \& Menon, S (2010). Teaching reading in the $21^{\text {st }}$ century: a glimpse at how special education teachers promote reading comprehension. Learning Disability Quarterly, 33(2), 59-74.

[19] Lindsay, J. (2014). Direct instruction really works!. Retrieve from http://www.jefflinsay.com/EducData.shtml.

[20] Lomibao, L. S., Luna, C. A., \& Namoco, R. A. (2016). The influence of mathematical communication on student's mathematics performance and anxiety. American Journal of Educational Research, 4(5), 378-382.

[21] Near, S. M. (2014). Literacy Instruction in Math Classes (Master's Thesis). Retrieved from http:/dspace.sunnyconn ect.suny.edu/handle/1951/64572.

[22] Oladayo, O. T. \& Oladayo, C. E. (2012). Effects of direct andindirect instructional strategies on students' achievement in mathematics. African Research Review (An International Multidisciplinary Journal, Ethiopia), 6(4), 349-361.

[23] Ogena, E. B., Laña, R. B., \& Sasota, R. S. (2008). Performance of Philippine high schools with special science curriculum in the 2008 trends in international mathematics and science study (TIMSS-advanced). Research paper presented at 11th National Convention on Statistics (NCS), EDSA Shangri-La Hotel.

[24] Rosenshine, B. (2008). Five meanings of direct instruction. Academic Development Institute. http://www. centerii.org/ search/Resources/Five DirectInstruct.pdf.
[25] Rust, A.H. (2011). The impact of instruction incorporating content area reading strategies on student mathematical achievement in a Community College Developmental mathematics course (Doctoral Dissertation). Available from ProQuest Dissertations \& Theses Global database. (UMI3495430).

[26] Sanford, K.L. (2015). Factors affecting the reading Comprehension of Secondary Students with disabilities (Doctoral Dissertation). Available from ProQuest Dissertations \& Theses Global database. (UMI 3716260).

[27] Shanahan, T., \& Shanahan, C. (2008). Teaching disciplinary literacy to adolescents: rethinking content-area literacy. Harvard Educational Review, 78(1), 40-59.

[28] Stokke, A. (2015). What to do about Canada's declining math Scores? Institut C.D. HOWE Institute Retrieved from http://search.proquest.com.

[29] Takami, L. J. (2009). A content analysis of reading strategies in Teacher Editions of Mathematics Textbooks (Doctoral Dissertation). Available from ProQuest Dissertations \& Theses Global database. (UMI 3401875).

[30] Learning, equity and accountability program support project. (2014). World Bank. Retrieved from http://projects.woldbank.org/P118904/national-program-supportbasic-education-2?lang=en. 